\title{
First report of powdery mildew caused by Erysiphe glycines on Hylodesmum podocarpum in Korea
}

\author{
In-Young Choi ${ }^{1} \cdot$ Young-Joon Choi ${ }^{2} \cdot$ Hyeon-Dong Shin $^{3}$ \\ Received: 1 October 2019 / Accepted: 6 January 2020 / Published online: 10 January 2020 \\ (C) Società Italiana di Patologia Vegetale (S.I.Pa.V.) 2020
}

Keywords Hylodesmum podocarpum $\cdot$ Powdery mildew $\cdot$ Erysiphe glycines

Hylodesmum podocarpum [syn. Desmodium podocarpum] is a medicinal plant in Asia. During 2015-2019, several dozen plants of $H$. podocarpum growing wild in Seoguipo, Korea, were found infected with a powdery mildew. Infections often caused leaf senescence and early defoliation. Voucher specimens have been deposited in the Korea University Herbarium (KUS). Conidiophores of the fungal agent causing the powdery mildew were cylindrical, measured 52-110 × 7-9 $\mu \mathrm{m}$, and were composed of 3-4 cells with straight foot-cells $24-40$ $\mu \mathrm{m}$ long. Conidia produced singly were oval to oblong-elliptical, 32-42 × 16-22 $\mu \mathrm{m}$, and devoid of distinct fibrosin bodies. Chasmothecia were dark brown, spherical, and 90-120 $\mu \mathrm{m}$ in diameter. Each chasmothecium contained 6-10 asci. Appendages were mycelioid, flexuous, 10 to 24 per chasmothecium, 0.5 to 4 times as long as the chasmothecial diameter and yellowish at the base, hyaline in the upper part. Asci were short stalked, 4-6-spored, and 50-68 $\times 30-42 \mu \mathrm{m}$. Ascospores were hyaline, ellipsoid-ovoid, and 20-30 × 12-16 $\mu \mathrm{m}$. The features were compatible with those of Erysiphe glycines F.L. Tai (Braun and Cook 2012). To confirm the identity of the causal fungus on KUS-F30196 (from $H$. podocarpum, Seoguipo, Korea, 2017) and two additional samples of F20400 (from H. podocarpum var. mandshuricum, Jinju, Korea, 2004) and F22178 (from H. podocarpum var. oxyphyllum, Pocheon, Korea, 2006), the internal transcribed spacer (ITS) regions of rDNA were amplified with the primers

Hyeon-Dong Shin

hdshin@korea.ac.kr

1 Department of Agricultural Biology, Chonbuk National University, Jeonju 54896, Korea

2 Department of Biology, Kunsan National University, Gunsan 54150, Korea

3 Division of Environmental Science and Ecological Engineering, Korea University, Seoul 02841, Korea
ITS5/P3 and sequenced. The resulting sequences were deposited in GenBank (MN420980, MN420982, and MN420981, respectively). A GenBank BLAST search revealed that the ITS sequences share $99.7-100 \%$ similarities with those of E. glycines ex Desmodium laxum (LC009948, LC028953) and ex Desmodium oxyphyllum (AB015927). Infections of E. glycines on Desmodium spp. have been known from China and Japan (Farr and Rossman 2019). To our knowledge, this is the first report of powdery mildew caused by E. glycines on H. podocarpum in Korea.

Acknowledgements This paper was supported by research funds for newly appointed professors of Chonbuk National University in 2019 to IYC.

\section{Compliance with ethical standards}

Conflict of interest The authors declare no conflict of interest.

\section{References}

Braun U, Cook RTA (2012) Taxonomic manual of the Erysiphales (Powdery Mildews). CBS Biodiversity Series No. 11. CBS, Utrecht, The Netherlands

Farr DF, Rossman AY (2019) Fungal databases, syst. Mycol. Microbiol. Lab., Online publication. ARS, USDA.

Publisher's note Springer Nature remains neutral with regard to jurisdictional claims in published maps and institutional affiliations. 